Borneo Journal of Science \& Technology, Volume (2), Issue (2), Pages: 39-46

DOI: http://doi.org/10.3570/bjost.2020.2.2-07

e-ISSN: 2672-7439

(c) 2018, UCTS Publisher.

\begin{tabular}{lll}
\hline Submitted: $10^{\text {th }}$ January 2020 & Accepted: $05^{\text {th }}$ May 2020 & Published: $31^{\text {th }}$ July 2020
\end{tabular}

\title{
Optimisation of Phenolic Compounds Extraction from Terung Asam Sarawak and Their Antioxidant Activity
}

\author{
*Hwong Chia Shing, Lau Joey Siao Jin, Koh Chen Chung, Hii Siew Ling \\ School of Engineering and Technology, University College of Technology Sarawak (UCTS), \\ 96000 Sibu, Sarawak, Malaysia
}

\begin{abstract}
Terung Asam Sarawak is a non-seasonal indigenous fruit vegetable in Sarawak. Exploration of the fruit's phytochemicals can encourage its consumption and prospective utilisation. Therefore, the objective of this study was to investigate the antioxidant properties of Terung Asam Sarawak. In the present study, a $2^{3}$ full factorial design was used to determine the optimum condition of three factors, namely temperature, time and agitation speed for the extraction of phenolic compounds and antioxidant activity of Terung Asam Sarawak. Whole fruits were freeze-dried and used for antioxidant properties analysis. The redness $\left(\mathrm{a}^{*}\right)$ of ripe fresh Terung Asam in this study was $12.57 \pm$ 1.60. The result showed that the highest total phenolic content (TPC, $16.16 \mathrm{mg} \mathrm{GAE} / \mathrm{g}$ extract) and antioxidant activity $\left(86.80 \%\right.$ ) were obtained after $16 \mathrm{~h}$ of extraction at $60^{\circ} \mathrm{C}$ with the speed of $250 \mathrm{rpm}$ using $80 \%$ methanol as extraction solvent. Predicted values were close to the experimental values obtained and thus indicated the adequacy and validity of the model. Furthermore, temperature, time and combination of the three factors had significant effects on the yield of TPC $(\mathrm{p}<0.05)$ whereas only time and combination of the three factors had significant effect on antioxidant activity of Terung Asam extract $(\mathrm{p}<0.05)$. Findings from this study could contribute to the body of knowledge of this underutilised indigenous fruit, particularly the extractability of phytochemicals from Terung Asam.
\end{abstract}

Keywords: Terung Asam / Terung Dayak, Solanum lasiocarpum Dunal, Optimisation, Total Phenolic Content (TPC), Antioxidant Activity, Full Factorial Design

\section{INTRODUCTION}

Terung Asam (Solanum lasiocarpum Dunal) is one of the common indigenous fruit vegetables in Sarawak. It is a native eggplant and is also known as Terung Dayak. The immature fruit is green and turns yellow to orange when it is ripe. Some have tints of dark purple. Given that it has a sour taste, it is commonly used as flavouring in many local dishes. In October 2010, Terung Asam was filed in the Geographical Indications (GI) certificate [1]. Terung Asam has received great attention as it has high nutritional values and antioxidant properties [2]. Researchers at the Department of Agriculture Sarawak have developed the Terung Asam into several products such as jam, puree, juice and dehydrated slices [3].

Antioxidants are important in helping human to maintain optimum health and act as first line of defence to the human body against free radical damage. The accumulation of free radicals in the body will result in a phenomenon known as oxidative stress, which will cause damage to the cell structures [4]. Oxidative stress contributes to the development of degenerative and chronic illness such as cancer, aging, autoimmune disorder, cardiovascular and neurodegenerative diseases [5]. Regular consumption of antioxidative fruits and vegetables can help in reducing the risk of chronic diseases [6]. This is mainly due to the presence of antioxidant constituents and bioactive compounds in fruits and vegetables, for instance, vitamin $\mathrm{C}$, carotenoids, phenolics, flavonoids, tannins and anthocyanins that can scavenge free radicals. Therefore, fruits and vegetables are the essential sources of antioxidant components with strong antioxidant activities [7];[8];[9].

Phenolic compounds are one of the major bioactive compounds in fruits. Phenolic compounds such as phenolic acids and flavonoids are commonly found in the flesh of fruits, and gallic acid is the major component among the phenolic acids. On the other hand, flavonoids and lignans can be found in their seeds or kernel [10]. Natural phenolic compounds from plant materials have sparked interest among consumers, food manufacturers and scientists because of their multiple biological and health effects, particularly antioxidant activity [11]. Some studies have suggested that the intake of phenolic compounds in daily diet could scavenge the free radicals

Corresponding Author: Hwong Chia Shing, School of Engineering and Technology, University College of Technology

Sarawak (UCTS), Email: cshwong14@ucts.edu.my 
released from cell metabolism and prevent the oxidative damage that causes ageing and age-related diseases [12].

Several extraction methods have been developed to extract the bioactive compounds from fruits and vegetables. Solvent extraction is the most common method used because of its efficiency, ease of use and wide applicability [13]. In order to achieve an optimal extraction, establishment of parameters is necessary as the efficiency of extraction is greatly relied on the type of material used [14]. Depending on the nature of the extraction process, parameters such as $\mathrm{pH}$, time, temperature, agitation, polarity of extractor liquid and particle size of extracted compound will affect the yield [13];[15].

Factorial design is a useful tool to screen the effects of multiple factors and their interactions on response variables and it requires fewer experimental runs if compared with classical optimisation experiment [16]. This study aimed to optimise the condition of extraction temperature $\left(30\right.$ to $\left.60^{\circ} \mathrm{C}\right)$, time $(0.5-16 \mathrm{~h})$ and agitation speed $(0-250 \mathrm{rpm})$ on the extraction yield of total phenolic content (TPC) and antioxidant activity of Terung Asam using two level, $2^{3}$ full factorial design, and to assess TPC and antioxidant activity of the extracts.

\section{MATERIALS AND METHODS}

\section{Chemicals}

Methanol, Folin-Ciocalteu phenol reagent (Rmstain), gallic acid monohydrate (Sigma-Aldrich), anhydrous sodium carbonate (R\&M) and DPPH (Sigma-Aldrich).

\section{Sample Preparation}

Six batches of ripe fresh Terung Asam were purchased from the local market in Sibu, Sarawak. Three pieces of Terung Asam from each batch were randomly selected for colour measurement using chromameter (Konica Minolta CR-400, Japan). Results were recorded as L*, $a^{*}$ and $b^{*}$ values, where $L^{*}$ describes lightness $(0$, black; 100, white), a* indicates redness (- green; + red), and $\mathrm{b}^{*}$ indicates yellowness (-blue; + yellow). Three measurements were made at different surfaces of the samples and the results were averaged. Whole fruits were then freeze-dried and blended into fine powder and stored at $-20^{\circ} \mathrm{C}$ for further analysis.

\section{Preparation of Extracts}

Extraction was conducted using $80 \%$ methanol according to the method described by Azeez et al. (2012) [17] with slight modifications in which two grams of ground samples were extracted with a total volume of $100 \mathrm{~mL}$ of $80 \%$ (v/v) methanol. The mixture of samples and $80 \%$ methanol were homogenised in the orbital shaker (SI-300, Jeio Tech, Korea) at different conditions as suggested by $2^{3}$ full factorial using Design Expert software version 10.0. The three factors under investigation were extraction temperature $\left(\mathrm{X}_{1}: 30-60^{\circ} \mathrm{C}\right)$, extraction time $\left(\mathrm{X}_{2}: 0.5-16 \mathrm{~h}\right)$ and agitation speed $\left(\mathrm{X}_{3}: 0\right.$ $250 \mathrm{rpm})$. The extract was then filtered by filter paper (Ross 4a) and concentrated at $60^{\circ} \mathrm{C}$ using a rotary evaporator (Buchi, Switzerland). Viscous extracts were stored at $-4^{\circ} \mathrm{C}$ for further analysis.

\section{Determination of Total Phenolic Content by Folin- Ciocalteu Assay}

Total phenolic content (TPC) in Terung Asam extracts was determined using the Folin-Ciocalteu (F-C) assay described by Lim et al. (2007) [18] with slight modifications. One millilitre of extract sample was mixed with $5 \mathrm{~mL}$ of $\mathrm{F}-\mathrm{C}$ reagent using vortex mixer (SA8, Stuart, UK) and kept in dark at room temperature for 10 mins. Four millilitres of sodium carbonate $(7.5 \%$ w/v) was then added into it and allowed to stand for 30 mins. The absorbance of the mixture was measured at $750 \mathrm{~nm}$ using a UV-Vis spectrophotometer (Cary 60, Agilent Technologies, Malaysia). TPC in the samples was calculated from the gallic acid calibration curve and reported in terms of gallic acid equivalent (mg of GAE/g of extract).

\section{Determination of Antioxidant Activities by DPPH Free Radical Scavenging Assay}

Antioxidant activity of extracts was determined using 2,2- Diphenyl-1-picrylhydrazyl radical radical (DPPH) assay as described by Azeez et al. (2012) [17] with slight modifications. To prepare $0.1 \mathrm{mM}$ DPPH solution, 0.02 $\mathrm{g}$ of DPPH was topped up with $500 \mathrm{~mL}$ methanol and stored in an amber bottle. One (1) $\mathrm{mL}$ of the extract solution and $1 \mathrm{~mL}$ of methanol acted as the control were mixed with $4 \mathrm{~mL}$ of DPPH solution respectively using vortex mixer. After a 20-min incubation in the dark at room temperature, the absorbance of the solution was measured at $517 \mathrm{~nm}$ against a blank of methanol using a UV-Vis spectrophotometer. Results were reported as percentage (\%) of inhibition of DPPH radical which was calculated by using the Equation 1 .

$\%$ of inhibition of DPPH $=\frac{A b s_{1}-A b s_{2}}{A b s_{1}} \times 100 \%$

Where, $\quad \mathrm{Abs}_{1}=$ Absorbance of control

$\mathrm{Abs}_{2}=$ Absorbance of sample

\section{Verification of Extraction using Optimised Condition}

Optimal conditions for extraction in terms of extraction temperature, time and agitation speed were obtained from a series of solutions generated by Design Expert software. The best solution with the highest desirability 
(1.000) was employed for the verification process as shown in Table 1.

Table 1: Optimum conditions for verification

\begin{tabular}{lcc}
\hline \multicolumn{1}{c}{ Parameters } & Goal & $\begin{array}{c}\text { Optimum } \\
\text { conditions }\end{array}$ \\
\hline Temperature $\left({ }^{\circ} \mathrm{C}\right)$ & $30-60$ & 60 \\
Time (h) & $0.5-16$ & 16 \\
Speed (rpm) & $0-250$ & 250 \\
TPC (mg GAE/g extract) & Maximum & 16.16 \\
Antioxidant activity (\%) & Maximum & 86.97 \\
\hline
\end{tabular}

*Desirability $=1.000$

In order to determine the adequacy and validity of the model, the predicted values of TPC and antioxidant activity of Terung Asam extract (Table 1) were compared with the actual experimental values by using the Equation 2.

Percentage error $=\frac{\text { Pred. } \text { value }- \text { Exp. value }}{\text { Pred. } \text { value }} \times 100 \%$

\section{Statistical Analysis}

All experiments were conducted in triplicate and the results were reported as mean \pm standard deviation (SD). Design Expert software, version 10.0 (STAT-EASE Inc. Minneapolis, USA) was used for the experiment design, statistical analysis of the optimisation and verification of the experimental data. Difference at $\mathrm{p}$ value $<0.05$ was considered statistically significant.

\section{RESULTS AND DISCUSSION}

\section{Optimisation of Extraction with Different Conditions}

The $\mathrm{L} * \mathrm{a} * \mathrm{~b} *$ of ripe Terung Asam used in this study was redness $\left(+a^{*}\right)$ of $12.57 \pm 1.60$, yellowness $\left(+b^{*}\right)$ of $70.52 \pm 1.68$ and lightness $\left(\mathrm{L}^{*}\right)$ of $74.39 \pm 1.33$.

The extraction condition was optimised using an experimental design of two-level, $2^{3}$ full factorial design with three parameters selected which were temperature, time and agitation speed. During optimisation process, the temperature range was set from $30^{\circ} \mathrm{C}$ to $60^{\circ} \mathrm{C}$ as the boiling point of methanol is $65^{\circ} \mathrm{C}$. Any temperatures that is higher than $65^{\circ} \mathrm{C}$ will cause methanol to boil and evaporate. The time was set from 0.5 hour to 16 hours while the agitation speed was set from $0 \mathrm{rpm}$ to $250 \mathrm{rpm}$ to prevent spillage of the solution from the flask if speed is higher than $250 \mathrm{rpm}$.

Table 2 shows the minimum TPC (12.88 mg $\mathrm{GAE} / \mathrm{g}$ of extract) and antioxidant activity (62.39\%) were obtained at the lowest extraction temperature of $30^{\circ} \mathrm{C}$, time 0.5 hours and speed of $0 \mathrm{rpm}$ whereas the maximum TPC (16.16 $\mathrm{mg}$ GAE/g of extract) and antioxidant activity $(86.80 \%)$ were obtained at the highest extraction temperature of $60^{\circ} \mathrm{C}$, time 16 hours and speed of $250 \mathrm{rpm}$.

The mean of TPC in Terung Asam was $14.50 \mathrm{mg}$ $\mathrm{GAE} / \mathrm{g}$ of freeze-dried fruit (equivalent to $14.53 \mathrm{mg}$ $\mathrm{GAE} / \mathrm{g}$ of extract) which is slightly lower than the TPC in dehydrated carrot (19.90 mg GAE/g) conducted by Lutz et al. (2015) [19]. Moreover, the mean antioxidant activity of Terung Asam was $77.32 \%$ which was relatively higher than the antioxidant activities of tomato (35.07\%) and brinjal (25.17-40.35\%) reported by Azeez et al. (2012) [17] and Kandoliya et al. (2015) [20] respectively.

\section{Effect of Extraction Conditions on Total Phenolic Content (TPC) of Terung Asam}

Analysis of Variance (ANOVA) of $2^{3}$ full factorial design for TPC is shown in Table 3. The model was significant $(\mathrm{p}<0.05)$ and the absence of lack of fit ( $p>0.05$ ) strengthened the reliability of the model. The coefficient of determination, $\mathrm{R}^{2}(0.86)$ was high and close to 1 . This implied that $86 \%$ of the experimental data was compatible with the data predicted by the model. Meanwhile, the adjusted- $\mathrm{R}^{2}(0.69)$ showed a moderately high degree of correlation between predicted and experimental values whereas the predicted- $\mathrm{R}^{2}(0.82)$ agreed with the adjusted- $\mathrm{R}^{2}$. Adequate precision (AP) measures the signal to noise ratio and a ratio greater than 4 is desirable. The AP result of 10.66 indicated an adequate signal and this model can be used to navigate the design space. In addition, coefficient of variation (CV) was small (2.80\%) demonstrated a high reliability of the experiments. Based on these results, the model was a good simulation of extraction experiment.

The ANOVA results indicated that the linear model terms of temperature (A), time (B) and combination of the three factors $(A B C)$ had significant effect on extraction of TPC from Terung Asam. Whereas speed (C) had no significant effect ( $p>0.05)$ on the extraction for TPC.

By using experimental data (Table 3), Equation 3 was generated which could be used to predict TPC in Terung Asam:

$\mathrm{TPC}=11.21775+0.053624 \mathrm{X}_{1}+0.19806 \mathrm{X}_{2}+0.013837 \mathrm{X}_{3}-$ $2.58065 \mathrm{E}-003 \mathrm{X}_{1} \mathrm{X}_{2}-2.51441 \mathrm{E}-004 \mathrm{X}_{1} \mathrm{X}_{3}-1.35484 \mathrm{E}-003 \mathrm{X}_{2} \mathrm{X}_{3}$ $+2.82151 \mathrm{E}-005 \mathrm{X}_{1} \mathrm{X}_{2} \mathrm{X}_{3}$

Where, $X_{1}$ represented temperature while $X_{2}$ and $X_{3}$ were time and agitation speed, respectively. 
Optimisation of Extraction Condition of Total Phenolic Content and Antioxidant Activity of Terung Asam Sarawak

Table 2: Experimental design for extraction

\begin{tabular}{cccccc}
\hline Run & $\begin{array}{c}\text { Temperature } \\
\left({ }^{\circ} \mathrm{C}\right)\end{array}$ & $\begin{array}{c}\text { Time } \\
(\mathrm{h})\end{array}$ & $\begin{array}{c}\text { Speed } \\
(\mathrm{rpm})\end{array}$ & $\begin{array}{c}\text { TPC } \\
(\mathrm{mg} \text { GAE/g extract })\end{array}$ & $\begin{array}{c}\text { Antioxidant } \\
\text { activity }(\%)\end{array}$ \\
\hline 1 & 30 & 16.00 & 250 & 14.29 & 74.81 \\
2 & 30 & 0.50 & 0 & 12.88 & 62.39 \\
3 & 60 & 0.50 & 250 & 14.18 & 71.09 \\
4 & 45 & 8.25 & 125 & 15.19 & 75.59 \\
5 & 60 & 16.00 & 0 & 15.12 & 81.35 \\
6 & 45 & 8.25 & 125 & 14.45 & 74.03 \\
7 & 45 & 8.25 & 125 & 13.82 & 76.67 \\
8 & 60 & 16.00 & 250 & 16.16 & 86.80 \\
9 & 30 & 0.50 & 250 & 14.39 & 80.67 \\
10 & 30 & 16.00 & 0 & 14.75 & 81.86 \\
11 & 45 & 8.25 & 125 & 14.75 & 75.60 \\
12 & 60 & 0.50 & 0 & 14.45 & 78.09 \\
13 & 45 & 8.25 & 125 & 14.52 & 81.68 \\
14 & 45 & 8.25 & 125 & 14.53 & 81.83 \\
Mean & & & & 14.53 & 77.32 \\
\hline
\end{tabular}

Table 3: ANOVA results of TPC

\begin{tabular}{lccccc}
\hline \multicolumn{1}{c}{ Source } & $\begin{array}{c}\text { Sum of } \\
\text { Squares }\end{array}$ & $\begin{array}{c}\text { Degree of } \\
\text { Freedom }\end{array}$ & Mean Square & F Value & $\begin{array}{c}\text { p-value } \\
\text { (Prob>F) }\end{array}$ \\
\hline Model & 5.98 & 7 & 0.85 & 5.16 & $0.0316^{*}$ \\
A - Temperature & 1.62 & 1 & 1.62 & 9.77 & $0.0204^{*}$ \\
B - Time & 2.44 & 1 & 2.44 & 14.73 & $0.0086^{*}$ \\
C - Speed & 0.41 & 1 & 0.41 & 2.50 & 0.1651 \\
AB & 0.097 & 1 & 0.097 & 0.58 & 0.4737 \\
AC & $9.800 \mathrm{E}-003$ & 1 & $9.800 \mathrm{E}-003$ & 0.059 & 0.8160 \\
BC & 0.054 & 1 & 0.054 & 0.33 & 0.5873 \\
ABC & 1.34 & 1 & 1.34 & 8.11 & $0.0292^{*}$ \\
Residual & 0.99 & 6 & 0.17 & & \\
Lack of Fit & $8.595 \mathrm{E}-004$ & 1 & $8.595 \mathrm{E}-004$ & $4.326 \mathrm{E}-003$ & 0.9501 \\
Pure Error & 0.99 & 5 & 0.20 & & \\
Cor Total & 6.98 & 13 & & & \\
$\mathrm{R}^{2}$ & 0.86 & & & & \\
Adjusted $\mathrm{R}^{2}$ & 0.69 & & & & \\
Predicted $\mathrm{R}^{2}$ & 0.82 & & & & \\
Adeq. Precision & 10.66 & & & & \\
\hline CV=2.80\%, *p $<0.05$ indicates significant effect. & & & & \\
& & & & & \\
\end{tabular}

Figure 1 shows the extraction temperature had positive effect on TPC in which the higher the extraction temperature, the higher the TPC in Terung Asam extract. In the present study, the highest TPC in Terung Asam extract (16.16 mg GAE/g of extract) was obtained at the highest temperature $\left(60^{\circ} \mathrm{C}\right)$ which is presented in run 8 of Table 2. This is due to the plant tissue became soften at high temperature and the interaction between phenolic compounds with protein and phenolic compounds with polysaccharides in the plant material is weaken [21]. This enhances the penetration of extraction solvent into the plant matrix, which will reduce the viscosity of the solvent and thus increase the diffusibility and solubility of phenolics [22,23,24,25]. According to Candrawinata et al. (2014) [26], concentration of phenolics in apple pomace extract was significantly affected by temperature $(\mathrm{p}<0.001)$, with the highest TPC obtained at $90^{\circ} \mathrm{C}$. Saci et al., (2017) [27] 
also stated in their study that extraction of phenolics from carob pulp, a beanlike fruit, was improved with temperature up to optimum temperature of $88.35^{\circ} \mathrm{C}$.

There was also a positive effect of extraction time on TPC (Figure 1). The highest TPC obtained in Terung Asam extract was $16.16 \mathrm{mg}$ GAE/ g of extract at the maximum extraction time $(16 \mathrm{~h})$ of this study which is shown in Table 2. According to Sampath (2013) [28], the plant cell wall is strong and a longer extraction time with an appropriate organic solvent is required to destabilise the strong cellulose structure of plant cell wall. In Sripum et al. (2017) study [29], they extracted phenolics from rice samples under various extraction time ranged from $0.5 \mathrm{~h}$ to $16 \mathrm{~h}$. The results reported that longer extraction time would result in higher extraction yield of TPC. Moreover, Butsat and Siriamornpun (2016) [30] studied the effect of extraction time on phenolic content in leaf extracts of Amomum chinense C., a kind of herb plant and the results revealed that TPC in the extract had increased with the prolonged extraction time from $6 \mathrm{~h}$ to $12 \mathrm{~h}$.

\section{Effect of Extraction Conditions on Antioxidant Activity of Terung Asam}

Analysis of Variance (ANOVA) of $2^{3}$ full factorial design for antioxidant activity is presented in Table 4. The model was significant $(\mathrm{p}<0.05)$ and the absence of lack of fit $(\mathrm{p}>0.05)$ indicated the model was reliable. In addition, the coefficient of determination, $\mathrm{R}^{2}(0.88)$ was high and close to 1 , adequate precision (AP) was 10.49 and coefficient of variation $(\mathrm{CV})$ was $3.98 \%$. The adjusted-R ${ }^{2}$ (0.73) also showed a moderately high degree of correlation between predicted and experimental values whereas the predicted-R $\mathrm{R}^{2}(0.65)$ was in agreement with the adjusted- $\mathrm{R}^{2}$. Based on the results, this model was fitted to determine the effects of extraction factors on antioxidant activity of Terung Asam.

The ANOVA results showed that the linear model terms of time (B) and combination of the three factors (ABC) had significant effect on antioxidant activity of Terung Asam extract. On the other hand, temperature (A) and speed (C) had no significant effect ( $p>0.05)$ on the extraction for antioxidant activity.
By using experimental data in Table 4, Equation 4 was generated and could be used to make prediction on the antioxidant activity of Terung Asam for given levels of each factor:

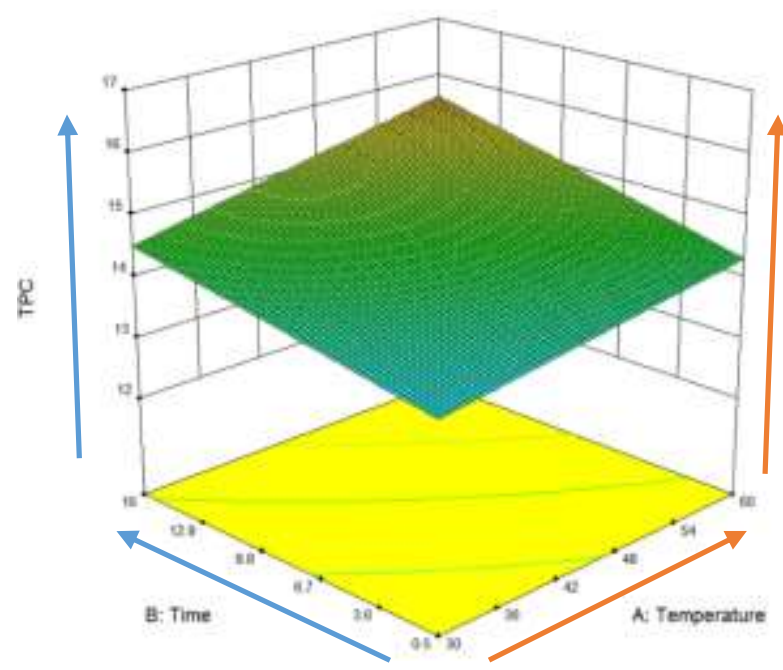

Figure 1: Response surface plot of effect of temperature and time on extraction of total phenolic content (TPC) from Terung Asam

DPPH (antioxidant activity) $=45.72510+0.54076 \mathrm{X}_{1}+$ $2.30194 \mathrm{X}_{2}+0.18238 \mathrm{X}_{3}-0.034860 \mathrm{X}_{1} \mathrm{X}_{2}-3.53316 \mathrm{E}-003 \mathrm{X}_{1} \mathrm{X}_{3}$ $-0.016286 \mathrm{X}_{2} \mathrm{X}_{3}+3.24989 \mathrm{E}-004 \mathrm{X}_{1} \mathrm{X}_{2} \mathrm{X}_{3}$

Where, $X_{1}$ represented temperature while $X_{2}$ and $X_{3}$ were time and agitation speed respectively.

The highest antioxidant activity $(86.80 \%)$ was obtained at the maximum extraction of temperature, time and speed as shown in run 8 of Table 2. However, the ANOVA result in Table 4 indicated that only extraction time had statistically significant effect on the antioxidant activity of Terung Asam extract ( $\mathrm{p}<0.05$ ). Candrawinata et al. (2014) [26] had reported that the optimal antioxidant activity of apple pomace extract was at longer time and higher temperature. 
Optimisation of Extraction Condition of Total Phenolic Content and Antioxidant Activity of Terung Asam Sarawak

Table 4: ANOVA result of antioxidant activity

\begin{tabular}{|c|c|c|c|c|c|}
\hline Source & $\begin{array}{l}\text { Sum of } \\
\text { Squares }\end{array}$ & $\begin{array}{l}\text { Degree of } \\
\text { Freedom }\end{array}$ & $\begin{array}{l}\text { Mean } \\
\text { Square }\end{array}$ & F Value & $\begin{array}{c}\text { p-value } \\
\text { (Prob>F) }\end{array}$ \\
\hline Model & 406.27 & 7 & 58.04 & 6.13 & $0.0210^{*}$ \\
\hline A - Temperature & 38.72 & 1 & 38.72 & 4.09 & 0.0897 \\
\hline B - Time & 132.68 & 1 & 132.68 & 14.01 & $0.0096^{*}$ \\
\hline $\mathrm{C}-$ Speed & 11.71 & 1 & 11.71 & 1.24 & 0.3087 \\
\hline $\mathrm{AB}$ & 3.59 & 1 & 3.59 & 0.38 & 0.5607 \\
\hline $\mathrm{AC}$ & 20.42 & 1 & 20.42 & 2.16 & 0.1924 \\
\hline $\mathrm{BC}$ & 20.74 & 1 & 20.74 & 2.19 & 0.1895 \\
\hline $\mathrm{ABC}$ & 178.42 & 1 & 178.42 & 18.84 & $0.0049 *$ \\
\hline Residual & 56.83 & 6 & 9.47 & & \\
\hline Lack of Fit & 0.65 & 1 & 0.65 & 0.058 & 0.8200 \\
\hline Pure Error & 56.18 & 5 & 11.24 & & \\
\hline Cor Total & 463.10 & 13 & & & \\
\hline $\mathrm{R}^{2}$ & 0.88 & & & & \\
\hline Adjusted $\mathrm{R}^{2}$ & 0.73 & & & & \\
\hline Predicted R² & 0.65 & & & & \\
\hline Adeq. Precision & 10.49 & & & & \\
\hline
\end{tabular}

\section{Optimisation and Verification of Model}

The extraction condition was optimised to maximise the yield of total phenolic content (TPC) and antioxidant activity of Terung Asam extract. In this study, the optimal condition would be at the highest level of temperature $\left(60^{\circ} \mathrm{C}\right)$, time $(16 \mathrm{~h})$ and speed $(250 \mathrm{rpm})$ as presented in Table 1.

As shown in Table 5, the maximum TPC and antioxidant activity of Terung Asam extract predicted were $16.16 \mathrm{mg}$ GAE/g of extract and $86.97 \%$ respectively and these were in agreement with the experimental value of $15.51 \mathrm{mg} \mathrm{GAE} / \mathrm{g}$ of extract (TPC) and $86.17 \%$ (antioxidant activity) as the differences were within $5 \%$. Therefore, this result verified that the model was satisfactory and accurate for reflecting the expected optimisation.

Table 5: Differences between predicted value and experimental value of TPC and antioxidant activity

\begin{tabular}{lccc}
\hline \multicolumn{1}{c}{ Response } & $\begin{array}{c}\text { Predicted } \\
\text { value }\end{array}$ & $\begin{array}{c}\text { Experimental } \\
\text { value }\end{array}$ & $\begin{array}{c}\text { Percentage } \\
\text { error }(\%)\end{array}$ \\
\hline $\begin{array}{l}\text { TPC (mg } \\
\text { GAE/g } \\
\text { extract) }\end{array}$ & 16.16 & 15.51 & 4.02 \\
$\begin{array}{l}\text { Antioxidant } \\
\text { activity (\%) }\end{array}$ & 86.97 & 86.17 & 0.92 \\
\hline
\end{tabular}

\section{CONCLUSION}

The present study reported that the total phenolic content (TPC) in Terung Asam ranged from 12.88 $16.16 \mathrm{mg} \mathrm{GAE} / \mathrm{g}$ of extract and it was also high in antioxidant activity $(62.39 \%-86.80 \%)$. The two-level, $2^{3}$ full factorial design was successfully used to identify the effects of extraction temperature, time and agitation speed on the yield of TPC and antioxidant activity of Terung Asam. Temperature and time had significant effects on the yield of TPC in Terung Asam extract $(p<0.05)$ with higher temperature and longer time of extraction would increase TPC productivity. In contrast, the antioxidant activity of Terung Asam extract was significantly influenced by extraction time $(\mathrm{p}<0.05)$ as its antioxidant activity was higher in longer time of extraction. The combination of three factors of temperature, time and agitation speed also showed a significant effect on the yield of TPC and antioxidant activity in Terung Asam extract $(\mathrm{p}<0.05)$. Finally, the optimised condition for maximum extraction of TPC and antioxidant activity of Terung Asam was found to be temperature of $60^{\circ} \mathrm{C}$, time of $16 \mathrm{~h}$ and speed of 250 rpm. Findings from this study could contribute to the body of knowledge of this underutilised indigenous fruit, particularly the extractability of phytochemicals from Terung Asam. Antioxidant property analysis according to fruit part such as seed, flesh and skin of Terung Asam is recommended for future research. 


\section{ACKNOWLEDGMENT}

The research was funded by internal grant (UCTS/RESEARCH/4/2016/01) of University College of Technology Sarawak (UCTS), Sibu, Sarawak, Malaysia.

\section{REFERENCES}

[1] A report: Umar, S, 2012. 'Terung Asam Sarawak', a Geographical Indications (GI) - registered product of Sarawak. [online] Available at: <www.doa.sarawak.gov.my/modules/web/downlo ad_show.php?id=1151> [Accessed 12 July 2019].

[2] Voon, B.H and Kueh, H.S, 1999. The nutritional value of indigenous fruits and vegetables in Sarawak. Asia Pacific Journal of Clinical Nutrition, 8(1): 24-31.

[3] A report: Dayod, M and Lim, L.L, 2015. Graft compatibility between Solanum lasiocarpum and Solanum torvum as a potential tool to mitigate soilborne diseases in Sarawak. [online] Available at: <https://www.omicsonline.org/2168-9881/21689881.S1.015-025.pdf> [Accessed 12 July 2019].

[4] Halliwell, B, 2007. Biochemistry of oxidative stress. Biochemical Society Transactions, 35(5), 1147-1150.

[5] Valko, M., Leibfritz, D., Moncol, J., Cronin, M.T.D., Mazur, M and Telser, J, 2007. Free radicals and antioxidants in normal physiological functions and human disease. The International Journal of Biochemistry \& Cell Biology, 39(1), 4484.

[6] Dembinska-Kiec, A., Mykkanen, O., Kiec-Wilk, B and Mykkanene, H, 2008. Antioxidant phytochemicals against type 2 diabetes. British Journal of Nutrition, 99(1), 109-117.

[7] Amin, I., Zamaliah, M.M and Chin, W.F, 2004. Total antioxidant capacity and phenolic content in selected vegetables. Food Chemistry, 87, 581-586.

[8] Battino, M., Beekwilder, J., Denoyes-Rothan, B., Laimer, M., McDougall, G.J and Mezzetti, B, 2009. Bioactive compounds in berries relevant to human health. Nutrition Reviews, 67, S145-S150.

[9] Tenore, G.C., Novellino, E and Basile, A, 2012. Nutraceuticals potential and antioxidants benefits of red pitaya (Hylocereus polyrhizus) extracts. Journal of Functional Foods, 4, 129-136.

[10] Cadenas, E and Packer, L, 2001. Handbook of antioxidants, revised and expanded. Second edition., Marcel Dekker, New York.

[11] Rice-Evans, C.A., Miller, N.J., Bolwell, P.G., Bramley, P.M and Pridham, J.B, 1995. The relative antioxidant activities of plant-derived polyphenolic flavonoids. Free Radical Research, 22(4), 375-383.
[12] Kurosumi, A., Sasaki, C., Kumada, K., Kobayashi, F and Nakamura, Y., 2007. Novel extraction method of antioxidant compounds from Sasa palmata (Bean) Nakai using steam explosion. Process Biochemistry, 42(10), pp. 1449-1453.

[13] Dai, J and Mumper, R. J, 2010. Plant phenolics: extraction, analysis and their antioxidant and anticancer properties. Molecules, 15(10), 73137352.

[14] Vinatoru, M, 2001. An overview of the ultrasonically assisted extraction of bioactive principles from herbs. Ultrasonics Sonochemistry, 8(3), 303-313.

[15] Wang, L and Weller, C.L, 2006. Recent advances in extraction of nutraceuticals from plants. Trends in Food Science and Technology, 17(6), 300-312.

[16] Andrade, R.A.M.S., Maciel, M.I.S., Santos, A.M.P., Melo, E.A, 2015. Optimization of the extraction process of polyphenols from cashew apple agro-industrial residues. Food Science and Technology, Campinas, 35(2), 354-360.

[17] Azeez, L., Adeoye, M.D, Majolagbe, T.A, Lawal, A.T and Badiru, R, 2012. Antioxidant activity and phytochemical contents of some selected Nigerian fruits and vegetables. American Journal of Chemistry, 2(4), 209-213.

[18] Lim, Y.Y., Lim, T.T and Tee, J.J, 2007. Antioxidant properties of several tropical fruits: a comparative study. Food Chemistry, 103(3), 10031008.

[19] Lutz, M., Hernandez, J and Henriquez, C, 2015. Phenolic content and antioxidant capacity in fresh and dry fruits and vegetables grown in Chile. CyTA - Journal of Food, 13(4), 541-547.

[20] Kandoliya, U.M., Bajaniya, V.K., Bhadja, N.K., Bodar, N.P and Golakiya, B.A, 2015. Antioxidant and nutritional components of eggplant (Solanum melongena L) fruit grown in Saurastra region. International Journal of Current Microbiology and Applied Science, 4(2), 806-813.

[21] Shi, J., Yu, J.M., Pohorly, J., Young, C., Bryan, M and $\mathrm{Wu}, \mathrm{Y}, 2003$. Optimisation of the extraction of polyphenols from grape seed meal by aqueous ethanol solution. Food, Agricultural and Environment, 1(2), 42-47.

[22] Hemwimon, S., Pavasant, P and Shotipruk, A, 2007. Microwave-assisted extraction of antioxidative anthraquinones from roots of Morinda citrifolia. Separation and Purification Technology, 54, 44-50.

[23] Silva, E.M., Souza, J.N.S., Rogez, H., Rees, J. F and Larondelle, Y, 2007. Antioxidant activities and polyphenolic contents of fifteen selected plant species from the Amazonian region. Food Chemistry, 101, 1012-1018. 
[24] Al-Farsi, M.A and Lee, C.Y, 2008. Optimisation of phenolics and dietary fibre extraction from date seeds. Food Chemistry, 108, 977-985.

[25] Wang, J., Sun, B. G., Cao, Y., Tian, Y and Li, X. $\mathrm{H}$, 2008. Optimisation of ultrasound-assisted extraction of phenolic compounds from wheat bran. Food Chemistry, 106, 804-810.

[26] Candrawinata, V.I., Golding, J.B., Roach, P.D and Stathopoulos, C.E, 2014. Total phenolic content and antioxidant activity of apple pomace aqueous extract: effect of time, temperature and water to pomace ratio. International Food Research Journal, 21(6), 2337-2344.

[27] Saci, F., Louaileche, H., Bachir bey, $\mathrm{M}$ and Meziant, L, 2017. Optimisation of phenolic compound recovery and antioxidant activity from carob pulp using response surface methodology. International Food Research Journal, 24(3), 10941101.
[28] Sampath, M, 2013. Optimisation of the extraction process of phenolic antioxidant from Polyalthia Longifolia (Sonn.) Thawaites. Journal of Applied Pharmaceutical Science, 3(2), 148-152.

[29] Sripum, C., Kukreja, R.K., Charoenkiatkul, S., Kriengsinyos, W and Suttisansanee, U, 2017. The effect of extraction conditions on antioxidant activities and total phenolic contents of different processed Thai Jasmine rice. International Food Research Journal, 24(4), 1644-1650.

[30] Butsat, S and Siriamornpun, S, 2016. Effect of solvent types and extraction times on phenolic and flavonoid contents and antioxidant activity in leaf extracts of Amomum chinense C. International Food Research Journal, 23(1), 180-187. 